\title{
POLA PENGEMBANGAN TUTURAN KADA TOMINAA DAERAH TANA TORAJA
}

\author{
Anastasia Baan \\ FKIP Universitas Kristen Indonesia Toraja
}

\begin{abstract}
ABSTRAK
Tujuan penelitian ini adalah memerikan pola pengembangan tuturan kada tominaa daerah Tana Toraja. Penelitian ini termasuk jenis penelitian kualitatif dengan menggunakan pendekatan hermeneutika. Data penelitian ini berupa tuturan kada tominaa daerah Tana Toraja, informasi tentang tradisi masyarakat daerah Tana Toraja, dan kegiatan sehari-hari masyarakat daerah Tana Toraja. Pengumpulan data dilakukan melalui studi dokumen, wawancara, dan observasi. Dalam pengumpulan data, peneliti sebagai instrumen kunci dilengkapi dengan panduan observasi, panduan wawancara, dan alat perekam (handycam). Analisis data dilakukan dengan mengikuti model hermeneutika dalam pandangan Ricoeur, yakni melalui level semantik, level refleksif, dan level eksistensial. Berdasarkan temuan penelitian, dikemukakan hasil penelitian sebagai berikut: pola pengembangan tuturan kada tominaa daerah Tana Toraja, meliputi (a) pola pengulangan, (b) pola penjelasan, dan (c) pola penegasan.
\end{abstract}

\section{THE UTTERANCE FORMATION PATTERNS OF KADA TOMINAA OF TANA TORAJA REGENCY}

\begin{abstract}
The aim of this research is to explain the utterance formation patterns of kada tominaa ofTanah Toraja Regency. This research is qualitative and employeda hermeneutic approach. The data of this research are kada tominaa utterances of Tana Toraja Regency, information about the tradition of Tana Toraja society, and daily activities of Tana Toraja society. To collect the data, document studies, interviews, and observations were performed. In collecting the data, the researcher as the key instrument was completed with observation guides, interview guides, and camcorders. Data analysis was carried out using a hermeneutic model in Ricoeur's perspective through semantic, reflexive, and existential levels. The result of this research shows that the utterance formation patterns of kada tominaa ofTanah Toraja Regency cover (a) repetition (b) explanation, and (c) affirmation.
\end{abstract}

\section{A. PENDAhUlan}

Kada tominaa daerah Tana Toraja merupakan salah satu sastra lisan di daerah Tana Toraja yang berwujud syair dan diwariskan dari mulutke mulut. Kada tominaa daerah Tana Toraja dituturkan oleh pemangku adat atau sekelompok orang dalam setiap upacara pemakaman adat daerah Tana Toraja atau yang disebut rambu solo'.Pada upacara pemakaman tersebut, kada tominaa biasanya dituturkan pada kegiatan singgi, badong, dan bating. Pada kegiatan singgi, kada tominaa dituturkan oleh seorang pemangku adat untuk menyampaikan pujian kepada si jenasah. Pada kegiatan badong, kada tominaa dituturkan oleh sekelompok orang dengan membuat lingkaran dan saling bergandengan tangan, sedangkan pada kegiatan bating, kada tominaa dituturkan secara bergantian oleh seorang lelaki dan perempuan dan biasanya diiringi musik seruling. Upacara pemakaman atau yang disebut rambu solo' merupakan bentuk penghargaan anak kepada orang tuanya yang dilaksanakan pada sore hari saat matahari mulai condong ke barat dan biasanya berlangsung tiga hari sampai seminggu.

Kada tominaa juga dituturkan oleh seorang pemangku adat pada berbagai kegiatan upacara syukuran atau yang disebut rambu tuka', misanya pada acara pernikahan atau yang disebut rampanan kapa', dan acara syukuran 
rumah adat, atau yang disebut mangrara tongkonan. Pelaksanaan upacara syukuran atau yang disebut rambu tuka' dilaksanakan pada pagi hari, yaitu sebelum matahari condong ke barat, dan biasanya diadakan hanya sehari saja.

Kada tominaa daerah Tana Toraja sebagai sasrta lisan yang memiliki kekhasan sendiri,selalu diekspresikan untuk kepentingankepentingan tertentu sesuai bunyi syair tersebut, artinya kada tominaa daerah Tana Toraja dijadikan sebagai salah satu media ekspresi masyarakat daerah Tana Toraja untuk mengkomunikasikan pengalaman hidupnya maupun kepentingan tertentu kepada sesamanya dalam lingkup masyarakat daerah Toraja. Saryono (2006:11) berpendapat bahwa tidak mungkin terjadi komunikasi tanpa tutur, dan tidak mungkin terbentuk jaringan sosial untuk melaksanakan kehidupan bersama tanpa tutur. Dengan demikian dapat dikatakan bahwa kebiasaan masyarakat daerah Tana Toraja yang sering memanfaatkan tuturan kada tominaa sebagai media komunikasi ini merupakan kekayaan budaya yang harus dipertahankan agar tidak mengalami kepunahan.

Pentingnya penggalian dan pendokumentasian tuturan kada tominaa sebagai sastra lisan karena tuturan kada tominaa merupakkan salah satu dari sekian banyak sastra lisan di Indonesia. Pendokumentasian tersebut perlu dilakukan karena bagi masyarakat daerah Tana Toraja budaya tulis masih sangat muda usianya. Karena itulah, dapat dikatakan bahwa tuturan kada tominaa hanya tersimpan di dalam ingatan orang tua atau budayawan saja yang jumlahnya semakin berkurang dimakan usia. Terkait dengan permasalahan tersebut, penelitian ini merupakan penelitian sastra lisan yang kajiannya akan difokuskan pada pola pengembangan tuturan kada tominaa daerah Tana Torajadengan menggunakan pendekatan hermeneutika.

\section{B. LANDASAN TEORI}

\section{Kada Tominaa sebagai Sastra Lisan}

Kada tominaa daerah Tana Toraja merupakan salah satu sastra lisan di daerah Tana Toraja yang berwujud syair dan diwariskan dari mulutke mulut. Kada tominaa daerah Tana Toraja dituturkan oleh pemangku adat atau sekelompok orang dalam setiap upacara pemakaman adat daerah Tana Toraja atau yang disebut rambu solo'.Pada upacara pemakaman tersebut, kada tominaa biasanya dituturkan pada kegiatan singgi, badong, dan bating. Pada kegiatan singgi, kada tominaa dituturkan oleh seorang pemangku adat untuk untuk menyampaikan pujian kepada si jenasah, pada kegiatan badong, kada tominaa dituturkan oleh sekelompok orang dengan membuat lingkaran dan saling bergandengan tangan, sedangkan pada kegiatan bating, kada tominaa dituturkan secara bergantian oleh seorang lelaki dan perempuan dan biasanya diiringi musik seruling.Upacara pemakaman atau yang disebut rambu solo' merupakan bentuk penghargaan anak kepada orang tuanya yang dilaksanakan pada sore hari saat matahari mulai condong ke barat dan biasanya berlangsung tiga hari sampai seminggu.

Kada tominaa juga dituturkan oleh seorang pemangku adat pada berbagai kegiatan upacara syukuran atau yang disebut rambu tuka', misanya pada acara pernikahan atau yang disebut rampanan kapa', dan acara syukuran rumah adat, atau yang disebut mangrara tongkonan. Pelaksanaan upacara syukuran atau yang disebut rambu tuka' dilaksanakan pada pagi hari, yaitu sebelum matahari condong ke barat, dan biasanya diadakan hanya sehari saja. Kada tominaa daerah Tana Toraja sebagai sasrta lisan yang memiliki kekhasan sendiri,selalu diekspresikan untuk kepentingan-kepentingan tertentu sesuai bunyi syair tersebut, artinya kada tominaa daerah Tana Toraja dijadikan sebagai salah satu media ekspresi masyarakat daerah Tana Toraja untuk mengkomunikasikan pengalaman hidupnya maupun kepentingan tertentu kepada sesamanya dalam lingkup masyarakat daerah Toraja.

Sastra lisan di dalam bahasa Indonesia merupakan terjemahan bahasa Inggris 'oral literature' yang secara harfiah artinya: (1) mengucapkan kata dalam percakapan, (2) mentransaksikan kata dari mulut, pembicaraan, verbal, secara teknis dapat divisualisasikan berupa tradisi lisan, kepustakaan lisan, pengakuan lisan, dan sebagainya. Sastra lisan sebenarnya adalah kesusateraan yang mencakup ekspresi kesusastraan warga suatu kebudayan yang disebarkan secara lisan dari mulut ke mulut (Hutomo, 1991:1).Sastra lisan merupakan institusi dan 
kreasi sosial yang menggunakan bahasa sebagai media. Hakikatnya sastra lisan adalah bagian khazanah pengungkapan dunia sastra yang tidak lepas dari pengaruh-pengaruh nilai-nilai baru yang hidup dan berkembang pada masyarakat (Pamungkas, 2012:114).

Kada tominaa merupakan salah satu sastra lisan yang diwariskan dari generasi ke generasi di kalangan masyarakat daerah Tana Toraja Hal tersebut sejalan dengan ciri-ciri sastra lisan yang dikemukakan Hutomo (1991:3) sebagai berikut.

1. Penyebarannya melalui mulut ke mulut.

2. Lahir di dalam masyarakat yang masih bercorak desa.

3. Menggambarkan ciri-ciri budaya suatu masyarakat.

4. Tidak diketahui siapa pengarangnya, karena itu menjadi milik masyarakat.

5. Bercorak puitis, teratur, dan berulang-ulang.

6. Tidak mementingkan fakta dan kebenaran, lebih mementingkan pada aspek khayalan yang tidak diterima oleh masyarakat modern.

7. Terdiri dari berbagai versi.

8. Bahasanya menggunakan gaya bahasa lisan, mengandung dialek, kadang-kadang diucapkan tidak lengkap.

Sastra lisan merupakan bagian dari tradisi lisan. Oleh karena itu seorang ahli sastra lisan perlu juga memahami tradisi lisan. Ciri-ciri tradisi lisan mencakup beberapa hal, yaitu (1) berupa kesusasteraan lisan, (2) berupa teknologi tradisional, (3) berupa unsur-unsur religi dan kepercayaan, (4) berupa kesenian, dan (5) berupa hukum (Hutomo, 1991:11). Tradisi lisan merupakan warisan leluhur yang abadi, yang mengandung dan menggunakan simbol penuh makna. Sastra lisan dapat berperan sebagai kekayaan budaya khususnya kekayaan sastra, sebagai modal apresiasi sastra sebab sastra lisan telah membimbing anggota masyarakat ke arah apresiasi dan pemahaman gagasan dan peristiwa berdasarkan praktik yang telah menjadi tradisi selama berabad-abad sehingga mudah didekati karena sudah dikenal oleh masyarakat (Sikki, dkk. 1986:1).

Tradisi lisan (oral tradition) hampir disamakan dengan folklor, karena semua kriteria folklor memenuhi kriteria tradisi lisan, sehingga bentuk tradisi lisan itu dapat disandingkan dengan bentuk folklor karena antara folklor dan tradisi lisan ibarat dua sisi mata uang logam yang saling berhubungan antara satu dengan yang lain. Bentuk-bentuk tersebut antara lain: cerita rakyat, nyanyian, pepatah, mite dan legenda. Namun demikian ada sebagaian orang yang memandang tradisi lisan lebih mewadahi aspirasi, sedang folklor sering dikonotasikan sebagai hal yang kebenarannya disangsikan (Sadi Hutomo, 1991:11).

Menurut etimologinya, folklor berasal dari dua kata dasar, yaitu folk dan lore. Folk adalah sekelompok orang yang memiliki ciri-ciri pengenal fisik, sosial, budaya, sehingga dapat dibedakan dari kelompok-kelompok lainnya, misalnya warna kulit, mata pencaharian, bahasa, taraf pendidikan, dan sebagainya. Atau dengan kata lain, folk sinonim dengan kolektif. Sedangkan lore adalah tradisi folk (Dundes dalam Danandjaja, 1991:1). Folklor merupakan bagian kebudayaan yang bersifat tradisional, tidak resmi, dan noninstitusional (Pusposari 2011:2).

Berdasarkan hal tersebut, Danandjaja menyimpulkan ciri-ciri folklor sebagai berikut. 1. Penyebaran dan pewarisannya biasanya dilakukan secara lisan (dari mulut ke mulut).

2. Bersifat tradisional.

3. Dalam berbagai versi.

4. Bersifat anonim.

5. Berpola.

6. Menjadi milik bersama (kolektif).

7. Bersifat polos dan lugu(Danandjaya, 1991:3).

Pada dasarnya bentuk sastra lisan kada tominaa sama halnya dengan sastra lisan lainnya. Pada awalnya istilah ini merupakan ciri peradaban primitif, karena tradisi merupakan bentuk warisan panjang. Sastra lisan merupakan warisan leluhur yang abadi, karena sastra itu ada, lestari, hidup, berkembang, secara alami dalam masyarakat. Sastra lisan telah berusia panjang seusia orang yang berkomunikasi lisan. Karena sastra lisan masyarakat daerah Tana Toraja merupakan bagian dari kebudayaannya yang diwariskan secara turun-temurun sebagai milik bersama maka sastra lisan muncul dengan berbagai bentuk sebagai penyalur sikap, pandangan, refleksi dan sebagainya. 


\section{Hermenutika sebagai Kajian Sastra Lisan}

Menurut Palmer (2003:14) akar kata hermeneutik berasal dari kata kerja Yunani hermeneuein yang berarti 'menafsirkan' dan kata benda hermeneia yang berarti "interpretasi". Istilah Yunani ini mengingatkan kita pada tokoh mitologis yang bernama Hermes yang digambarkan sebagai seseorang yang mempunyai kaki bersayap dan lebih banyak dikenal sebagai Mercurius dalam bahasa Latin. Tugas Hermes adalah menerjemahkan pesan-pesan dari gunung Olympus ke dalam bahasa yang dapat dimengerti oleh umat manusia. Berhasil tidaknya misi itu sepenuhnya tergantung pada cara bagaimana pesan itu disampaikan. Oleh karena itu, hermeneutik pada akhirnya diartikan sebagai proses mengubah sesuatu atau situasi ketidaktahuan menjadi mengerti.

Mediasi dan proses membawa pesan 'agar dipahami' yang diasosiasikan dengan Hermes ini terkandung di dalam tiga bentuk makna dasar dari hermeneuein dan hermeneia dalam penggunaan aslinya. Ketiga bentuk ini menggunakan bentuk verb dari hermeneuein, yaitu (1) mengungkapkan kata-kata, misalnya, to say; (2) menjelaskan, seperti menjelaskan situasi; 3 menerjemahkan, seperti di dalam transliterasi bahasa asing. Ketiga makna itu bisa diwakili dengan bentuk kata kerja Inggris 'to interpret'.

Hermeneutikdapat didefinisikan dalam enam bentuk, yaitu pertama, hermeneutika sebagai teori eksegesis Bible, yakni sistem tafsir untuk mengungkapkan makna tersembunyi di balik teks Bible. Kedua, hermeneutika sebagai metodologi fisiologi secara umum, yakni berfungsi menafsirkan teks-teks dengan mengaitkannya dengan fakta historis teks tersebut. Ketiga, hermeneutika sebagai ilmu pemahaman linguistik, artinya sebagai alat interpretasi terhadap bahasa yang dianggap sebagai kunci pemahaman. Keempat, hermeneutika sebagai pondasi metodologis bagi Geisteswissenschaften. Kelima, hermeneutika sebagai fenomenologi dasein dan pemahaman eksistensial. Keenam, hermeneutika berfungsi sebagai sistem interpretasi (Palmer, 2003:38).

Betti (dalam Sumaryono, 1995:30) mengatakan bahwa tugas orang yang melakukan interpretasi adalah menjernihkan persoalan mengerti, yaitu dengan cara menyelidiki setiap detail proses interpretasi. Dengan kata lain interpretasi sebagai sarana untuk mengerti. Orang yang melakukan interpretasi harus mengenal pesan atau kecondongan sebuah teks, lalu ia harus meresapi isi teks. Mengerti secara sungguh-sungguh hanya akan dapat berkembang bila didasarkan atas pengetahuan yang benar. Suatu arti tidak akan kita kenal jika kita tidak rekonstruksi. Hukum Betti 'tentang interpretasi' yang terkenal yaitu sensus non eas inferendus sed efferendus (makna bukanlah diambil dari kesimpulan melainkan diturunkan). Jadi seorang penafsir tidak boleh bersikap pasif, ia harus mengkonstruksi makna.

Suatu interpretasi dibutuhkan apabila ada pluralitas makna. Tujuan hermeneutika adalah menghilangkan sebuah misteri yang terdapat dalam sebuah simbol. Setiap interpretasi adalah usaha untuk 'membongkar' makna-makna yang masih terselubung dalam makna kesusastraan (Ricoeur dalam Sumaryono,1995:98). Suatu proses pemahaman dapat dilakukan melalui tiga langkah, yakni: (1) langkah simbolik, yaitu pemahaman dari simbol ke simbol, (2) pemberian makna oleh simbol serta penggalian yang cermat atas makna, dan (3) berpikir dengan menggunakan simbol serta titik tolakanya. Ketiga langkah ini berhubungan erat dengan tiga tahap pemahaman bahasa, yaitu: (1) tahap semantik, (2) tahap refleksi, dan (3) tahap eksistensial (Ricoeur, 2003:210).

Setiap penafsiran harus dimulai dari tahap semantik. Tahap ini dipandang penting karena setiap ontologi diekspresikan melalui wahana bahasa. Pada tahap ini, penafsiran terhadap suatu makna cerita dilakukan dengan mengkaji struktur bahasa atau aspek kebahasaan beserta keseluruhan sistem simbolnya. Simbol merupakan struktur penandaan yang di dalamnya sebuah makna langsung atau pokok menunjuk kepada makna lain yang tidak langsung. Di dalam interpretasi ini pluralitas makna termanifestasikan.

Tahap kedua ialah tahap refleksi, yakni menghubungkan bahasa simbolik dengan pemahaman diri. Asumsi dasarnya ialah bahasa sendiri sebagai kumpulan penandaan harus mengacu kepada eksistensi. Oleh karena itu, penafsir harus membuat dirinya cocok dengan 
teks, mencocokkan makna teks dengan dirinya sendiri, serta mengenal teks seakan-akan mengenal dirinya sendiri. Pada tahap ini, pemahaman dapat dikembangkan dengan cara memahami orang lain.

Tahap ketiga adalah tahap eksistensial merupakan tahap hermeneutika yang paling kompleks. Tahap ini dikenal pula sebagai tahap ontologi. Pada tahap ini tersingkap bahwa pemahaman dan makna ternyata berakar dari dorongan-dorongan yang lebih mendasar dan bersifat instingtif, yakni hasrat. Eksistensi dapat diperoleh dengan menyesuaikan makna-makna tersebut dengan kerja, institusi, dan monumen kultural.

\section{METODOLOGI PENELITIAN}

\section{Pendekatan dan Jenis Penelitian}

Penelitian ini mengkaji ekspresi metaforis dalam tuturan kada tominaa daerah Tana Toraja. Dalam hal ini, secara teoretis kada tominaa di daerah Tana Toraja dipandang sebagai produk budaya berupa sastra lisan yang mencerminkan budaya penuturnya. Untuk memahami ekspresi metaforis dalam kada tominaa diperlukan kajian secara mendalam melalui pengumpulan data secara lengkap dan penafsiran serta penjelasan makna secara tepat.

Pendekatan yang digunakan dalam penelitian ini adalah pendekatan hermeneutika. Pendekatan hermeneutika yang dimaksud adalah menurut pandangan Ricoeur, yakni pemahaman pada (a) tahap semantik, (b) tahap refleksif, dan (c) tahap eksistensial. Dalam konteks hermeneutika, tuturan kada tominaa daerah Tana Toraja dipandang sebagai cerminan kehidupan masyarakat daerah Tana Toraja, sehingga kosakata ekspresi metaforis, pesan yang terkandung, dan gaya tutur ekspresi metaforis yang terungkap dalam tuturan kada tominaa daerah Tana Toraja merupakan gambaran budaya masyarakat daerah Tana Toraja.

\section{Lokasi Penelitian}

Kada tominaa merupakan sastra lisan masyarakat daerah Tana Toraja. Daerah Tana Toraja merupakan salah satu kabupaten yang ada di provinsi Sulawesi Selatan yang terletak di sebelah utara Makassar sebagai ibu kota provinsi Sulawesi Selatan. Ibukota Kabupaten Tana
Toraja terletak sekitar $329 \mathrm{~km}$ arah Utara Kota Makassar yang melalui Kabupaten Enrekang, Kabupaten Sidrap, Kota Pare-pare, Kabupaten Barru, Kabupaten Pangkep dan Kabupaten Maros.

Letak Geografis kabupaten Tana Toraja yang ibukotanya Makale secara geografis terletak di bagian UtaraProvinsi Sulawesi Selatan yaitu antara $2^{\circ}-3^{\circ}$ Lintang Selatan dan $119^{\circ}$ - $120^{\circ}$ Bujur Timur, dengan luas wilayah tercatat 2.054,30 $\mathrm{km}^{2}$ persegi, dengan batas-batas, yaitu sebelah utara adalah kabupaten Toraja Utara,sebelah Selatan adalah Kabupaten Enrekang, Sebelah Timur adalah Kabupaten Luwu, sebelah Barat adalah Propinsi Sulawesi Barat.

\section{Data dan Sumber Data Penelitian}

Data penelitian ini berupa teks tuturan kada tominaa daerah Tana Toraja. Data yang berupa teks ini dikelompokkan dalam dua kategori, yakni data berupa (a) tuturan kada tominaa pada kegiatan rambu tuka', yaitu kegiatan yang berhubungan dengan syukuran masyarakat daerah Tana Toraja. Kegiatan yang dimaksud adalah syukuran pernikahan atau yang disebut rampanan kapa dan syukuran rumah atau yang disebut mangrara tongkonan, dan (b) tuturan kada tominaa pada kegiatan rambu solo', yakni kegiatan yang berhubungan dengan upacara pemakaman masyarakat daerah Tana Toraja. Kegiatan yang dimaksud adalah kegiatan singgi,badong, dan bating. Setelah dikategorikan diperoleh data tentang kosakata ekspresi metaforis, pesan yang disampaikan, dan gaya tutur ekspresi metaforis dalam tuturan kada tominaayang sesuai dengan masalah dalam penelitian ini. Data tersebut merupakan data yang mengekspresikan metaforis dalam tuturan kada tominaa daerah Tana Toraja.

Selain berupa teks tuturan kada tominaa, data penelitian ini juga berupa informasi tentang tradisi budaya dan tindakan masyarakat. Data-data tersebut dimanfaatkan untuk memperkuat dan mempertajam penafsiran makna yang berkaitan dengan fokus masalah yang diteliti. Data tersebut berupa ihktisar dokumen dan catatan peneliti. Data yang telah disebutkan di atas berasal dari beberapa sumber. Data yang berupa tuturan kada tominaa bersumber dari rekaman hasil wawancara dengan pelaku kada 
tominaa, dokumen tertulis serta hasil rekaman kada tominaa yang telah tersedia dalam Compact Disk (CD) yang memiliki relevansi dengan informasi dari informan. Data tentang tradisi budaya bersumber dari informasi para informan dan dokumen-dokumen tertulis. Sementara, data tentang tindakan masyarakat bersumber dari catatan peneliti ketika melakukan observasi.

Informan dalam penelitian ini ada dua macam: yakni informan terpilih dan informan bebas. Informan terpilih terdiri atas pelaku kada tominaa dan pakar bahasa Toraja, sedangkan informan bebas adalah beberapa orang dalam masyarakat Toraja yang ditemui peneliti secara acak. Melalui informan terpilih, peneliti menggali data tentang (a) kada tominaa dalam bentuk tulisan, (b) rekaman kaset atau rekaman $\mathrm{CD}$, (c) kondisi dan perkembangan kada tominaa, (d) tradisi budaya etnis Toraja. Sementara melalui informan bebas, peneliti menggali data tentang (a) teks kada tominaa yang dikenal oleh masyarakat dan (b) tradisi budayayang ada dalam masyarakat.

Dalam menentukan informan terpilih, peneliti menerapkan beberapa persyaratan, yaitu: (1) beretnis Toraja, (2) tinggal di wilayah Toraja (3) aktif dan berpengalaman dalam tradisi etnis Toraja, (4) menguasai kada tomina daerah Toraja, dan (5) peduli pada perkembangan dan pengembangan bahasa Toraja.

\section{Analisis Data}

Analisis data dilakukan sejak awal pengumpulan data. Saat mengumpulkan data, peneliti melakukan reduksi data, penyajian data, dan penarikan kesimpulan. Demikian seterusnya, dilakukan secara berulang-ulang sampai diperoleh simpulan yang benar-benar memadai. Menurut Miles dan Huberman (1992: 19) bahwa reduksi data, penyajian data, dan penarikan kesimpulan sebagai sesuatu yang jalin menjalin pada saat sebelum, selama, dan sesudah pengumpulan data dalam bentuk yang sejajar yang disebut analisis data model interaktif.

Analisis data pada penelitian ini menggunakan pendekatan hermeneutika menurut Recouer, yaitu pemahaman (verstehen) secara cermat melalui tahap semantik, tahap refleksif, dan tahap eksistensial. Pada level semantik, dilakukan pembacaan dan pemahaman tuturan lagu se- cara cermat dengan cara mengidentifikasi data, mengklasifikasi data, dan mengkategorisasi data sesuai dengan permasalahan dalam penelitian ini. Pada level refleksif, dilakukan penggayutan data temuan dari tuturan kada tominaa dengan perilaku budaya, tradisi budaya, dan lingkungan sosial budaya masyarakatnya. Kemudian, pada level eksistensi, dilakukan penafsiran makna data dengan melibatkan seluruh informasi yang menghasilkan temuan holistik emik.

\section{PEMBahasan}

Berdasarkan pola pengembangan tuturannya, tuturan kada tominaa daerah Tana Toraja dapat dikelompokkan menjadi tiga pola, yakni (a) pola pengulangan, (b) pola penjelasan, dan (c) pola penegasan. Ketiga pola tersebut diuraikan berikut ini.

\section{Pola Pengulangan}

Pola pengulangan digunakan dalam tuturan kada tominaa untuk memperjelas makna tuturan dengan cara menyatakan hal atau keadaan secara berulang-ulang. Pengulangan ini menggunakan kata yang maknanya sama atau hampir sama atau yang disebut pengulangan dengan menggunakan sinonim. Pola pengulangan yang dimaksud dapat lihat pada kegiatan singgi (Data.1Sing1.1-4) dan pada kegiatan badong (Data.1Bad2.1-6) berikut ini.

\section{/La kulambi'mo//dadinna/ \\ La kudete'//garaganna/ \\ /To nene'//mendeatanna/ \\ /To dolo//kapuanganna/}

\section{/Akan kudapat//kelahirannya/ \\ /Akan kucapai//kejadiannya/ \\ /Nenek moyang//dewanya/ \\ /Orang leluhur//Tuhannya/}

(Data.1Sing1)

Tahap semantik:

Tuturan la kulambi'modadinna dalam kada tominaa tersebut bermakna 'akan kudapat kelahirannya', la kudete'garaganna bermakna 'akan kucapai kejadiannya', tuturan to nene'mendeatanna bermakna nenek moyang Dewanya, dan tuturan to dolokapuangannabermakna 'orang leluhur Tuhannya'. 
Tahap reflektif:

Tuturan la kulambi'modadinna, la kudete'garaganna,to nene'mendeatanna, to dolokapuanganna merupakan tuturan yang saling bersinonim. Tuturan yang bersinonim tersebut adalah pada kata kulambi' 'kudapat' bersinonim dengan kudete' 'kucapai' karena sama-sama bermakna 'menemukan'. Kata dadinna, 'kelahiranya' bersinonim dengan garaganna 'kejadiannya' karena samasama bermakna 'pembuatan'. Kata to nene' 'nenek moyang' bersinonim dengan to dolo 'orang leluhur' karena sama-sama bermakna 'orang yang telah duluan meninggal', dan mendeatanna 'Dewanya' bersinonim dengan kapuanganna 'Tuhannya' karena samasama bermakna 'yang disembah'.

Tahap eksistensial:

Tuturan la kulambi'modadinna, la kudete' garaganna,to nene'mendeatanna, to dolokapuanganna dalam kada tominaa tersebut merupakan gaya tutur ekspresi metaforis kada tominaa yang pola pengembangan tuturannya berupa pola pengulang-an .

Demikian juga pada data.1Bad2.1-5 kata rio-rio, bating mario-riokan, makarorrong, rammangkan, dan sukkunkan 'sedih, meratap, sepi,diam, berduka' merupakan kata bersinonim. Tuturan tersebut dapat diamati pada kada tominaa berikut ini.

/Rio-rio/mentarampak
/Bating/messa'de banua
/Mario-rio/kan kami
/Makarorrong/silelekan
/Rammang/kanmassolanasang
/Sukkun/kan angge mairi'

Rasa/sedih/serumah

/Ratapan/ sekeliling rumah

Kami /bersedih/

Kami semua /sepi/

Kami semua/diam/

Kami semua/berduka/

(Data.1Bad2)

Tahap semantik:

Tuturan rio-rio, bating mario-riokan, makarorrong, rammangkan, dan sukkunkan dalam kada tominaa tersebut bermakna 'sedih, meratap, sepi,diam, berduka'
Tahap reflektif:

Tuturan rio-rio, bating mario-riokan, makarorrong, rammangkan, dan sukkunkan dalam kada tominaa tersebut merupakan kata bersinonim karena kata-kata tersebut memiliki makna yang sama yaitu 'orang yang sedang berduka'. Tuturan kada tominaa tersebut menceritakan tentang satu keluarga yang berduka karena ditinggal mati oleh salah satu anggota keluarganya.

\section{Tahap eksistensial:}

Tuturan rio-rio, bating mario-riokan, makarorrong, rammangkan, dan sukkunkan dalam kada tominaa tersebut merupakan gaya tutur ekspresi metaforis kada tominaa yang pola pengembangan tuturannya berupa pola pengulangan .

\section{Pola Penjelasan}

Pola penjelasan merupakan pengembangan tuturan yang dilakukan dengan menambahkan kata-kata tertentu yang sebagai penjelas atau penegas maksud tuturan. Kata penjelas dalam tuturan kada tominaa daerah Tana Toraja yang dimaksud kata penjelas yang berupa pasangan tetap untuk menegaskan maksud tuturannya. Kata-kata tersebut ditemukan dalam beberapa tuturan kada tominaa seperti pada kegiatan singgi(Data.1Sing16.1-4) berikut ini.

To makaka nauranni,

Sa'bua' natarandakki

Ma'pare rantel puangta

Sali papa solanasang

Bangsawan akan kehujanan,

Hamba pun basah kuyup

Allah kita/tak pandang bulu/

Semua sama di hadapannya

(Data.1Sing16)

Tahap semantik:

Tuturan ma'pare-rante dalam kada tominaa tersebut bermakna 'tak pandang bulu'.

Tahap reflektif:

Pada data tersebut, kata yang berpola penjelasan berupa pasangan tetap yaitu pada kata ma' pare-rante 'tak pandang-bulu'. Kata tersebut menjelaskan bahwa Allah itu maha adil terhadap semua manusia, karena 
Allah tidak membeda-bedakan umatnya, semua manusia sama di mata Allah.

Tahap eksistensial:

Tuturan ma' pare-rante dalam kada tominaa tersebut merupakan gaya tutur ekspresi metaforis kada tominaa yang pola pengembangan tuturannya berupa pola penjelasan.

Selain pada data tersebut, pola penjelasan berupa pasangan tetap juga tedapat pada kegitan bating(Data.1Bat6.3-4) berikut ini.

Petawa manda nabenki'

Sola kadisi-disian

/Totangmerremme'rakka'na/

/Tang mennoton tarunona/

Tawanya yang dia berikan

Dan senyumannya

Orang yang/ tidak bertumpang tangan/

Orang yang/tidak lepastangan/

(Data.1Bat.6)

Tahap semantik:

Tuturan totang merremme'-rakka'na, dan tang mennoton-tarunona pada kada tominaa tersebut bermakna 'orang yang tidak bertumpang-tangan, dan orang yang tidak lepas-tangan'.

Tahap reflektif:

Tuturan totang merremme'-rakka'na, dan tang mennoton-tarunona dalam kada tominaa tersebut merupakan kata yang berpasangan tetap, yaitu pada kata Kata-kata tersebut mengacu pada orang yang selalu menolong sesamanya.

Tahap eksistensial:

Tuturan totang merremme'-rakka'na, dan tang mennoton-tarunona dalam kada tominaa tersebut merupakan gaya tutur ekspresi metaforis kada tominaa yang pola pengembangan tuturannya berupa pola penjelasan.

Selanjutnya pada kegiatan rampanan kapa (Data.2Ram9.1-4) disebutkan pula kata yang berpasangan tetap. Kata tersebut dapat diamati pada tuturan kada tominaa berikut ini. Anna tontong lumingka /lurekke lusau'/ Untete kuli'na padang

Unnola kapadanganna

Rika siang-sianganna
Sehingga tetap berjalan /ke sana kemari/

Melalui rumput

Melewati alang-alang

Yang tumbuh lebat

(Data.2Ram 9$)$

Tahap semantik:

Tuturan lurekke-lusau' pada kada tominaa tersebut bermakna 'kesana-kemari'.

Tahap reflektif:

Tuturan lurekke-lusau' 'kesana-kemari' pada kada tominaa tersebut merupakan kata yang berpasangan tetap yang menggambarkan keadaan seseorang yang masih sehat dan masih mampu bekerja.

Tahap eksistensial:

Tuturan lurekke-lusau' dalam kada tominaa tersebut merupakan gaya tutur ekspresi metaforis kada tominaa yang pola pengembangan tuturannya berupa pola penjelasan.

Kemudian pada kegiatan mangrara tongkonan (Data.2Mang8.1-4) disebutkan pula kata yang berpasangan tetap. Kata tersebut dapat diamati pada tuturan kada tominaa berikut ini. Tahap semantik:

Tuturan mamase-liu kaboro' pada kada tominaa tersebut bermakna 'kasih-sayang' Tahap reflektif:

Tuturan mamase-liu kaboro' pada kada tominaa merupakan kata yang berpasangan tetap. Kata tersebut mengacu pada 'kasih sayang serta pemeliharaan Tuhan yang senantiasa Dia berikan kepada umat-Nya'. Kata-kata yang telah disebutkan di atas merupakan kata-kata yang berpasangan secara tetap. Kata-kata tersebut memiliki frekuensi penggunaannya dalam percakapan sehari-hari masyarakat Tana Toraja. Kata yang dimaksud dapat dicermati pada tuturan kada tominaa berikut.

Anna puang matua mora

La sumpu /mamase liu kaboro'/

Tarru' lamakari tutu

Lako batang ri kalena

Tuhanlah saja

Yang akan memberi /kasihsayang/

Sangat memelihara 
Kepada dirinya

(Data.2Mang8)

Tahap eksistensial:

Tuturan mamase-liu kaboro' dalam kada tominaa tersebut merupakan gaya tutur ekspresi metaforis kada tominaa yang pola pengembangan tuturannya berupa pola penjelasan .

Tahap eksistensial:

Tuturan mamase-liu kaboro' dalam kada tominaa tersebut merupakan gaya tutur ekspresi metaforis kada tominaa yang pola pengembangan tuturannya berupa pola penjelasan .

\section{Pola Penegasan}

Dalam tuturan kada tominaa daerah

Tana Toraja, terdapat kata yang pemaparannya menggunakan kata yang berlebih-lebihan, yakni kata yang isinya dibesar-besarkan melebihi kenyataan yang sebenarnya. Penggunaan pola yang dimaksudkan untuk menunjukkan intensitas suatu ekspresi, misalnya pada kegiatan singgi(1Sing16.1) yang menyebutkan kosakata natarandakki. Kosakata tersebut dapat damati pada tuturan kada tominaa berikut.

To makaka nauranni,

Sa'bua'/natarandakki/

Ma' pare rante puangta

Sali papa solanasang

Bangsawan akan kehujanan

Hamba pun /basah kuyup/

Allah kita tak pandang bulu

Semua sama di hadapannya

(Data.1Sing16)

Tahap semantik:

Tuturan 'natarandakki pada kada tominaa tersebut bermakna 'basah kuyup'.

Tahap reflektif:

Tuturan 'natarandakki pada kada tominaa tersebut merupakan kata yang berlebihlebihan yaitu pada di mana kata 'basah' diperjelas dengan kata 'kuyup'. Dalam tuturan tersebut menceritakan bahwa semua manusia akan mengalami suatu kematian, karena Allah tidak membeda-bedakan umatnya, sehingga semua sama di mata Allah.
Tahap eksistensial:

Tuturan 'natarandakki dalam kada tominaa tersebut merupakan gaya tutur ekspresi metaforis kada tominaa yang pola pengembangan tuturannya berupa pola penegasan.

Kata berpola penegasan juga terdapat pada kegiatan mangrara tongkonan (Data.2Mang11.4) berikut ini.
Anna siduppa ewanan sanda manapa'
Bulawan sanda makamban
Malumme-lummena rara'
/Umbalimbingna bulawan/

Supaya mendapat harta dengan jujur

Emas yang tebal

Mulus murni

/Emas mulia/

(Data.2Mang11)

Tahap semantik:

Tuturan umbalimbingna bulawan pada kada tominaa tersebut bermakna'emas mulia'.

Tahap reflektif:

Tuturan umbalimbingna bulawan pada kada tominaa merupakan kata yang berpola penegasan di mana kata 'emas' diperjelas dengan kata 'mulia' yakni mengacu pada kekayaan atau harta yang diperoleh secara halal.

Tahap eksistensial:

Tuturan umbalimbingna bulawan dalam kada tominaa tersebut merupakan gaya tutur ekspresi metaforis kada tominaa yang pola pengembangan tuturannya berupa pola penegasan .

\section{E. SIMPULAN}

Berdasarkan temuan penelitian, dikemukakan hasil penelitian sebagai berikut.

Pola pengembangan tuturan kada tominaa daerah Tana Toraja, meliputi (a) pola pengulangan, (b) pola penjelasan, dan (c) pola penegasan. Pola pengulangan digunakan dalam tuturan kada tominaa untuk memperjelas makna tuturan dengan cara menyatakan hal atau keadaan secara berulang-ulang. Pengulangan ini menggunakan kata yang maknanya sama atau hampir sama atau yang disebut pengulangan dengan menggunakan sinonim. Pola penjela- 
san merupakan pengembangan tuturan yang dilakukan dengan menambahkan kata-kata tertentu yang sebagai penjelas atau penegas maksud tuturan. Kata penjelas dalam tuturan kada tominaa daerah Tana Toraja yang dimaksud kata penjelas yang berupa pasangan tetap untuk menegaskan maksud tuturannya. Penggunaan pola yang dimaksudkan untuk menunjukkan intensitas suatu ekspresi.

\section{DAFTAR PUSTAKA}

Bogdan \& Biklen. 1990. Riset Kualitatif untuk Pendidikan. Jakarta: Depdikbud Proyek Pengembangan Pusat Fasilitas Bersama Antar-Universitas

Danandjaja, James. 1984. Foklor Indoesia: Ilmu Gosip, Dongeng, dan Lain-Lain. Jakarta: Grafiti

Hutomo, Suripan Sadi. 1991. Mutiara yang Terlupakan. Pengantar Studi Sastra Lisan. Surabaya. HISKI Jatim

Liliweri, Alo. 2003. Makna Budaya dan Komunikasi Antarbudaya. Yogyakarta: LKIS

Koentjaraningrat. 2003. Pengantar Antropologi. Jakarta. Rineka Cipta

Palmer, Richard. 2003. Hermeneutika: Teori Baru Mengenai Interpretasi. Diterjemahkan oleh Musnur Heri. Yogyakarta: Penerbit Pustaka Pelajar
Pusposari, Dewi. 2011. Mitos dalam Kajian Sastra Lisan. Malang: Pustaka Kaiswaran dan Fakultas Sastra Universitas Negeri Malang

Pamungkas, Sri. 2012. Bahasa Indonesia dalam Berbagai Persfektif. Yogyakarta: C.V Andi Offset

Ricoeur, Paul. 2003. Filsafat Wacana: Membelah Makna dalam Anatomi Bahasa. Diterjemahkan oleh Musnur Hery. Yogyakarta: IRCiSod

Rani, Abdul. 2006. Analisis Wacana: Sebuah Kajian Bahasa dalam Pemakaian. Malang. Banyumedi

Suyitno. 2010. Mengenal Budaya Etnik melalui Pemahaman Wacana Budaya. Malang: A3 (Asah, Asih, Asuh)

Sumaryono. 1995. Hermeneutika: Sebuah Metode Filsafat. Yogyakarta: Kanisius

Sikki, Muhammad. dkk. 1986. Struktur Sastra Lisan Toraja. Jakarta: Depdikbud

Soedjito \& Djoko Saryono. 2011. Kosakata Bahasa Indonesia. Malang: Aditya Media

Saryono, Djoko. 2006. Pergumulan Estetika Sastra di Indonesia. Malang: Pustaka Kayutangan 